\title{
Reflecting on the nature of knowledge
}

In February 1905, George Potts (1877-1948) was appointed the first professor of natural science at Grey University College, Bloemfontein, then a constituent college of the University of the Cape of Good Hope. He had been trained in dairy agriculture in England and obtained a PhD in botany from the University of Halle (1902). ${ }^{1}$ A council member of the South African Association for the Advancement of Science since its foundation in 1902, Potts was president in 1914 of Section C (bacteriology, botany, zoology, agriculture, forestry, physiology, hygiene and sanitary science). In his presidential address to Section $C$ that year, Potts reflected that '...to anyone acquainted with university education, BA denotes a man of literature and education, a man of culture, but by contrast, when a BSc is given by the same University it implies a barbaric Goth, a technical expert, a mere specialist, more or less respectable, but not admissible into the cultured caste'2.

Interestingly, Potts did not use the word 'scientist', and it may come as a surprise to many to discover that the term was first coined by William Whewell only in 1833 and was not in general use until many decades thereafter. Whewell, a renowned polymath and co-founder of the British Association for the Advancement of Science, invented 'scientist' (on the analogy with 'artist') to replace the phrase 'natural philosopher' that had, until then, been the professional appellation of those who worked in the 'sciences'. ${ }^{3}$

However, by 1959, exactly 60 years ago, the word scientist needed no introduction and practitioners no apology. That year C.P. Snow's Rede lectures were published as The Two Cultures and the Scientific Revolution and created vigorous debate around the primacy of the intellectual enquiry followed through differing academic mega-disciplines - the humanities and the sciences - to which Potts had alluded. There is no doubting that Snow, a Cambridge University PhD chemist at the Cavendish Laboratory, but also a novelist and playwright, over-emphasised the split between the two, but in the post-Cold-War world of the 1950s it was science and technology that dominated the future of human advancement. ${ }^{4}$

Snow's work spawned other investigations of the 'two cultures'. One of the most powerful was biologist E.0. Wilson's 1998 Consilience: The Unity of Knowledge (consilience, 'jumping together', is another Whewell-invented word). Wilson discussed the various attempts to unite the natural sciences that might be helpful in bringing them closer to the humanities as the 21 st century dawned. Referring to the need for synthesis to aid understanding and progress in a world of complex systems, Wilson sought reductionist laws that would unite the two camps. ${ }^{5}$ More gently, Stephen Jay Gould's posthumous The Hedgehog, the Fox, and the Magister's Pox: Mending and Minding the Gap Between Science and the Humanities (2003) focused on aspects that were common to the two, not what divided them. These included the possibility (and the thrill) of discovery, creative thinking and the need for evidence-based knowledge. The dichotomy, argued Gould, was a false one. ${ }^{3}$ The most recent contribution to this stream of thinking is
David Lowenthal's Quest for the Unity of Knowledge, a series of lectures that Lowenthal delivered at KTH in Stockholm in $2012 .{ }^{6}$ The underlying theme of the book is the fundamental intellectual, and essentially human, conundrum of unity versus diversity, cohesion versus collision, certainty versus doubt. Unlike Snow, Wilson and Gould, however, Lowenthal does not promote any particular path to rapprochement, but explains how various fields of inquiry arose and how they danced around one another for centuries, vying for attention and credibility, the balance shifting with time, place and context. Which mode of knowing was superior or more useful? 'Deterministic generalising' or 'real-life uncertainty'? 'Lumping or splitting'? The general or the specific? The search for order or celebration of disorder?

All too often, we pursue research rather narrowly, without time or opportunity to step back and reflect critically on the philosophy of the knowledge in which we engage and that we aim to produce. I hope that the South African Journal of Science will provide a vehicle for discussions on this topic within the context of our country and our continent at a critical time when reliable, creative knowledge in all fields is vital to our continued well-being and the Journal welcoming to all scholarly endeavours.

As incoming Editor-in-Chief, I look forward to working with the multidisciplinary and talented team of Associate Editors, and with Linda Fick, Managing Editor, and Nadine van der Merwe, Online Publishing Systems Administrator, together with Himla Soodyall, Executive Officer of ASSAf, and the Editorial Advisory Board. I thank John Butler-Adam, the outgoing Editor-in-Chief, for his generosity and kindness while I have been taking over the reins from him, and salute him for his energy, efficiency and dedication during his tenure of office that has seen great strides in the quality and reach of our journal.

\section{References}

1. Boucher M. Spes in Arduis: A history of the University of South Africa. Pretoria: University of South Africa; 1973. p.102

2. Potts G. Rural education. In: Report of the Twelfth Annual Meeting of the South African Association for the Advancement of Science, Kimberley, 1914. Cape Town: The Association; 1915. p. 57-76.

3. Gould SJ. The hedgehog, the fox, and the magister's pox: Mending and minding the gap between science and the humanities. London: Jonathan Cape; 2003. p. 206; p. 247-260. https://doi.org/10.4159/harvard.9780674063402

4. Snow CP. The two cultures. Cambridge: Cambridge University Press; 2008.

5. Wilson EO. Consilience: The unity of knowledge. New York: Vintage Books; 1998.

6. Lowenthal D. Quest for the unity of knowledge. London: Routledge; 2019. p. 3 , p. 17; p.18. https://doi.org/10.4324/9780429464706

HOW TO CITE:

Carruthers J. Reflecting on the nature of knowledge. S Afr J Sci. 2019;115(5/6), Art. \#6223, 1 page. https://doi.org/10.17159/sajs.2019/6223 